\title{
The marks of the church in South Africa today - In dialogue with Jürgen Moltmann on his 80th birthday ${ }^{1}$
}

P J Naude

(Nelson Mandela Metropolitan University)

\section{ABSTRACT \\ The marks of the church in South Africa today - In dialogue with Jürgen Moltmann on his 80th birthday}

In this celebration of Moltmann's 80th birthday, an ecclesiological reading of his well known trilogy, Theology of hope, The crucified God, and The church in the power of the Spirit is attempted. It is asserted that Moltmann's discussion of the marks of the church is a high point and summary of his early theological development. These insights are then applied to the situation of the church in South Africa today. The article closes with four contextual questions which are then "answered" in terms of the marks of the church.

On 8 April 2006 we have celebrated the 80th birthday of renowned German systematic theologian, Jürgen Moltmann. To mark the occasion, two separate Festschriften, both edited by Michael Welker (Heidelberg) and Miroslav Volf (Yale), recently appeared. The two books, with distinct contents, both take the doctrine of the Trinity as their focus and were published as Trinity and God's life (Fortress 2006) and Der lebendige Gott als Trinität (Gütersloher Verlaghaus 2006).

Moltmann is considered as the most influential Reformed theologian in the second half of the twentieth century. Whereas Barth and Bonhoeffer - and to slightly lesser extent Paul Tillich dominated the first half of the twentieth century, Moltmann stepped onto the theological scene with his remarkable Theologie der Hoffnung in 1964. This re-establishing of theology as future-oriented eschatology in a time of heightened tensions between East and West; the threat of nuclear war; the growth of regional conflicts; and the realization of the limits of our ecosystem, is compared to the groundbreaking direction given by Karl Barth’s Römerbrief in 1918, directly after the First World War (Welker and Volf 2006:9).

1 Revised version of a paper read at the annual meeting of the Theological Society of Southern Africa in Pietermaritzburg, 22 June 2006. 
This was followed by Der gekreuzigte Gott (1972, ET The crucified God 1974) which reinterpreted and criticized theology from the radical perspective of the cross of Christ. "Either Jesus who was abandoned by God is the end of all theology or he is the beginning of a specifically Christian, and therefore critical and liberating, theology of life” (Moltmann 1974:4).

The openness to the future explicated in Theology of hope, and the political liberation expounded in The crucified God (see specifically 1974:317ff) provided a crucial impetus for what became known as liberation theologies in Latin America ${ }^{2}$ and elsewhere, including South Africa ${ }^{3}$.

The third book of what grew into a coherent trilogy, carried the title Kirche in der Kraft des Geistes (1975, ET The church in the power of the Spirit 1977). Moltmann himself explains in the preface: "It looks as if I have now arrived theologically at the Pentecost and the sending of the Spirit, having started from Easter and the foundation if the Christian hope and travelled by way of Good Friday and the exploration of God's suffering”. All three books have to do with "the wealth of God's liberating dealings with the world. That is why I shifted emphasis from 'the resurrection of the crucified Jesus' in Theology of Hope to 'the cross of the risen Christ' in The Crucified God. Both perspectives would be incomplete if 'the sending of the Spirit', its messianic history and the charismatic power of its church were not added” (1977: xvi-xvii).

It is immediately evident that these early works of Moltmann advanced a renewed Christology from the perspectives of

2 Moltmann's imagery of an "exodus church" and his discussion of the political dimensions of the gospel, as well as the expressly "political theology" of Catholic scholar, J B Metz, clearly influenced Latin American theologians like Gustavo Gutierrez and Jon Sobrino. They, however, developed their own interpretations and focal points, and later impacted on European theology as well. See Moltmann's references to Gutierrez in Moltmann 1977:364, 373 and 400-401. On the theme of ecclesiology, Sobrino's The true church and the poor also discusses the four marks of the church and strongly draws on Moltmann's insights (see Sobrino 1984:98 - 124).

3 For a general discussion of Moltmann's influence on South Africa, see Dirkie Smit's contribution to the English Festschrift mentioned above (Smit 2006). He refers inter alia to Daniel Louw, Jaap Durand and the theological series on dogmatics published by Jonker and Durand (see footnote 12). 
resurrection (hope) and cross (suffering), as well as a socio-historical interpretation of the Trinity. Even the third book on the church has a Christological subscript: "A contribution to messianic ecclesiology" (my emphasis).

It is, however, argued in this paper that Moltmann's implicit concern has been the church. He did not only turn to ecclesiology as an "afterthought" as though a focus on resurrection and cross did not also spell out a new vision of and for the church. In fact, one can show that the very intention of Theology of hope was ecclesiological:

After establishing the eschatological nature of revelation in critical dialogue with Kant, Barth and Bultmann (1977:45-68) ${ }^{4}$, Moltmann explicates the promissiological character of the Old Testament as a "word of promise" (1977:102-105). He then turns to the New Testament and depicts the resurrection of Jesus as the opening up of a new future. Exactly because of the promise and hope, "the as yet unrealised future of the promise stands in contradiction to the given reality. The historic character of the reality is experienced in this contradiction, in the front line between the present and the promised future” (1977:225).

The crucial question is now: How will this contradiction between "promise" and "reality" be overcome? For Moltmann the answer lies in the church: "The promissio of the universal future leads of necessity to the universal missio of the Church to all nations”. The very structure of Moltmann's historically conditioned eschatology precludes all ideas of narrow evangelical mission: The church comes about via the justification of the godless, and this "leads immediately to the hunger for divine right in the godless world, and to the struggle for public, bodily obedience" (1967:225). In what would later become a dominant metaphor in liberation theologies, Moltmann concludes his great treatise on hope with a chapter devoted to the church as "exodus" community (1967:304ff).

$4 \quad$ Moltmann discusses the link between revelation and eschatology. He depicts his three dialogue partners as follows: Kant as developing a transcendental eschatology based on human reason, Barth as developing a theology of the transcendental subjectivity of God, and Bultmann as the transcendental subjectivity of man. 
In a poignant analysis of religion in a post-industrial, postEnlightenment society, Moltmann shows the threefold adaptation of the church to the demands of society: The church stabilizes and is a servant of this society by providing a private, romantic escapism ("the cult of transcendental subjectivity"), or by creating a smallgroup of co-humanity, compensating for loss of community in a technocratic world ("the cult of co-humanity"), or by providing a stabilising role and some institutionally derived security to ensure meaning in closing, secularist world ("the cult of the institution").

This socially imposed neutralizing of the gospel's power is the basis for Moltmann's concept of the exodus church: "If Christianity, according to the will of him in whom it believes and in whom it hopes, is to be different and to serve a different purpose, then it must address itself to no less a task than that of breaking out of these socially fixed roles... If the God who called them to life should expect of them something other than what modern industrial society expects and requires of them, then Christians must venture an exodus and regard their social roles as a new Babylonian exile" (Moltmann 1967:320).

The world is neither a hell of self-estrangement, nor yet finished. It is - in the light of a promissiological theology - a world of possibilities. "To disclose to it (the world, PJN) the horizon of the future of the crucified Christ is the task of the Christian Church" (Moltmann 1967:338, my emphasis). This is the last sentence in Theology of Hope - a fundamentally ecclesiological book.

The same ecclesiological theme can be detected in The crucified God. It may even be cited as the very reason behind the book. In the explanation of the theme at the beginning, Moltmann already writes that if people are to be freed from the facts of the present time and step into the freedom of a new future, "church and theology must turn to the crucified Christ... This is essential if they wish to become what they assert they are: the church of Christ, and Christian theology" (Moltmann 1974:1, my emphases).

He consequently argues for a dialectical in stead of analogical theology, because God is known in his opposite, namely in the

5 See section V of Theology of Hope. 
incarnation and crucifixion of Jesus of Nazareth ${ }^{6}$. Therefore the church must, "for the sake of its identity in the crucified Christ, reveal him (Christ) and itself, by following him, in what is different and alien" (1974:28). This is the only way to overcome the false oppositions in the church between "evangelisation" (verticalism) and "humanization" (horizontalism) sometimes expressed in "the crisis of identity" versus "the crisis of relevance" (1974:25).

When he outlines the resistance of the cross against its interpretation, Moltmann explicitly refers to the following of the cross as the "active imitation of the crucified Christ" on the part of those who follow him (1974:53). The followers of Christ - because they are crucified with Christ and take up their cross - move beyond the purely private into the political realm. "The suffering of love for forgotten, despised and betrayed human beings wherever they are oppressed is concrete suffering in imitation of Christ, and in practice can be called taking one's cross upon oneself” (1974:64).

One could say that the Christological and Trinitarian expositions in the middle part of the book (chapters 3-6), are the development of a dialectical theology of the cross that for Moltmann should determine the self understanding of the church. The cross of Christ, embodied in the church of the crucified one, is the way toward both the psychological (1974:291-316) and political liberation of humanity (1974: 317-340).

This political liberation (or rather liberations) are concretely expounded in Moltmann's moving and well-known five-fold "vicious circles of death" (1974:329-332) followed by "ways toward liberation" (332-335). It is worth quoting his expression of God's presence amidst these circles of death - only possible on the basis of a theology of the cross, and only mediated (at least partially) by a church of the cross:

"In the vicious circle of poverty it can be said: God is not dead. He is bread. In the vicious circle of force God's

6 Moltmann shows clear affinity with Luther in this passage: "If the principle of analogy alone is followed, the result would be a theologia gloriae, applicable in heaven only." And then we hear Barth in the background: "It is the dialectical knowledge of God in his opposite which first brings heaven down to the earth of those who are abandoned by God, and opens heaven to the godless" (Moltmann 1974:28). 
presence is experienced as liberation for human dignity and responsibility. In the vicious circle of alienation his presence is perceived in the experience of human identity and recognition. In the vicious circle of the destruction of nature God is present in joy and existence in peace between man and nature. In the viscous circle of meaninglessness and god-forsakenness, finally, he comes forward in the figure of the crucified Christ, who communicates the courage to be” (Moltmann 1974:337338).

Moltmann then closes this discussion (and the book as a whole) with a telling remark which may be construed as a bridge to the third volume in the trilogy: "In accordance with theological tradition it is possible to see this real presence of God, pointing beyond itself, as the history of the Spirit which comes upon all flesh. We understand it here as the process of the Trinitarian history of God".

Ecclesiology is clearly implied by this view: In Scripture the gift of the Spirit "which comes on all flesh" is the fulfilment of a prophetic promise (Joel 2) which marks the birth of the New Testament church (Acts 2). From the creeds (both Nicene and Apostolicum) we learn that faith in the Trinitarian God is the foundation of our belief in the church whose mission is nothing else than the missio Dei, the embodiment of the crucified God amidst the suffering of history.

It is therefore understandable that the third book, The church in the power of the Spirit, makes its practical intention quite clear, namely "to point away from the pastoral church that looks after the people, to the people's own communal church among the people... Missionary churches, confessing churches and 'churches under the cross' are fellowship churches, or inescapably become so. They do not stray into social isolation but become a living hope in the midst op the people” (1977:xvi).

The implicit ecclesiological theme of the two previous books are now taken up explicitly without loosing sight of the Trinitarian foundation of the church: The church is the church of Jesus Christ 
(Christology, 1977:66-132) ${ }^{7}$, it is the church of the kingdom of God (theology, 1977:133-196) $)^{8}$, and it is the church in the presence and power of the Holy Spirit (pneumatology, 1977:197-336) ${ }^{9}$.

The exodus church, founded on the resurrection, carries hope in the world and opens the vista of a new future (volume 1) exactly when it is the church of the cross (vol 2) who lives in the power of the Holy Spirit (volume 3). There is an inextricable link and theological coherence among Easter Sunday, Good Friday and the Day of the Pentecost.

Moltmann's discussion and reinterpretation on the marks of the church can be seen as the high point of his early theological development. His discussion of the marks not only closes the trilogy (Moltmann 1977:337-361), but harbours in itself and presupposes the rich theological foundations laid earlier. It must therefore not be read in isolation from this wider framework, a rough sketch of which was attempted thus far.

I wish to highlight and reinterpret freely three remarks by Moltmann as preface to an actual discussion of the marks of the church in South Africa today:

1. The marks of the church are confessed as part of the creed. The structure of both Nicea and the Apostolicum sees the church as the result of the Trinitarian God's saving history in the world. Ecclesiology is always embedded in theology, and any discussion of the nature and mission of the church should be derived from the nature and mission of God in Christ and the Spirit. The marks are statements of faith in the characteristics of Christ, statements of hope

7 'Without Christ, no church'. This simple sentence expresses an incontrovertible fact. There is only a church if and so long as Jesus of Nazareth is believed and acknowledged as the Christ of God" (Moltmann 1977:66).

8 "Christian eschatology is not merely eschatology for Christians; if it is to be eschatology of the all-embracing kingdom, it must also be unfolded as the eschatology of Israel, of the religions, of human social systems and of nature (Moltmann 1977:135, see the footnote references to both Barth and Bonhoeffer on page 378 ).

$9 \quad$ "The church lives in the history which finds its substantiation in the resurrection of the crucified Christ and whose future is the al-embracing kingdom of freedom. The living remembrance of Christ directs the church's hope towards the kingdom... The present power of this remembrance and this hope is called 'the power of the Holy Spirit'” (Moltmann 1977:197). 
about the coming of God's kingdom and statements of action (love) in the power of the Spirit that turns "normativities" into "realities" (Moltmann 1977:338-340).

2. The four marks of the church - unity, holiness, catholicity and apostolicity - serve as pointers to the essential, but have never been meant as restriction. Moltmann rightly points out that Luther responding to the situation of his time - identified seven signs of the true church. This "gives us liberty to move other marks of the true church into the foreground in a changed world situation, and to link these to the traditional ones" (1977:340).

New contexts - in my view - require at least a fourfold hermeneutical movement: an interpretation of the church's "social and political Sitz im Leben"; the development of new, complementary marks of the church that are oriented to this situation; a reinterpretation of the traditional marks in the light of the first two interpretations; and last (or first!) a re-reading of the Biblical traditions relevant to these signs. If we do not engage in this process, the church "would be forsaking the cross of its Lord and would be turning into the illusionary church, occupied merely with itself” (1977:342).

3. The signs of the church serve a twofold purpose: It reorientates the church inwardly toward its own origin and tradition. It helps to reshape the church's identity in times of change and conflict. Secondly, it serves an "outward" purpose as the church's public witness to the world. Depending on the situation, both are important, but for Moltmann, "an ecclesiology oriented towards the conflict of the world situation of today” takes precedence (1977:342).

Moltmann then develops an extended version of the traditional signs: unity in freedom, catholicity in a partisanship; holiness in poverty, and apostolicity in suffering (1977:342-361). If we wish to remain true to Moltmann's charge to steer clear of an illusionary church, we should not merely repeat what he wrote in the context of Western Europe and the world of the late 1960's and early 1970's. Learning from him (and others), we should venture into our own hermeneutical tasks and construct our own relevant interpretations of the signs of the church in Africa and the South Africa of the early 21st century. 
It is obviously not possible to construct a full contextual analysis, declare all theological assumptions ${ }^{10}$, and reinterpret the doctrine of the church in South Africa in a short paper like this. But the greater task should not inhibit us from drawing a rough first sketch.

The method I follow is to first point out the most important questions facing us as South Africans. This reveals my reading of the situation $^{11}$ at the moment, Moltmann's social and political Sitz im Leben. Thereafter I (like Moltmann) will not develop new marks of the church, but - in close relation to select Biblical traditions - rather extend and reinterpret the traditional ones as "responses" to the contextual questions posed.

Here are the four suggested questions and related responses:

\section{HOW DO WE CREATE COMMUNITY IN A SITUATION OF CONFLICTING INTERESTS AND IDENTITIES? THROUGH THE UNITY OF THE CHURCH.}

The struggle against apartheid was a struggle for the right to be "the same”. It was the dream for equality under a system that viciously misused differences of culture and language to divide and rule. The system received political legitimisation from a neo-Kuyperian missiological theology that saw God as the great Differentiator and (consequently) the institutional church as a God-willed disunited

10 One assumption needs clarification, namely that the church (still) matters. My personal conviction does not rely on positive experiences, but on the fact that I view the church from the perspective of the economic trinity. In some instances only the church in its institutional form can embody the marks of the church. Unity immediately springs to mind. In other instances the church as salt and light, i.e. ordinary Christians living in the world (sometimes outside the institutional structures), is able to make true the confessions about the church. The discussion of holiness and apostolicity below might fall into this category. Moltmann has been influenced quite strongly by his teacher, Otto Weber, and emphasises the local faith community as well as the institutional and ecumenical forms of the church (see Moltmann 1977:1-18).

11 When Steve de Gruchy discusses the church in a post-apartheid South Africa, he outlines "four key struggles" facing us now: national reconciliation, human sexuality and gender justice, pluralism in a secular state, and dealing with the promise and peril of globalisation (De Gruchy 2004: 224-255). 
church, reflecting racial and cultural "diversity" in its blessed seperatedness ${ }^{12}$.

Those who suffered under the system had a common enemy with the consequence that for them identity questions were literally restricted to "black" versus "white". After 1994, Tinyiko Maluleke remarks: "Issues of culture are again acquiring a new form of prominence in various spheres of South African society. It is as if we can, at last, speak truly and honestly, about our culture. This is due to the widespread feeling that now, more than at any other time, we can be the subjects of our own cultural destiny... we must recover our own selves" (quoted in Balcomb 1998:70, my emphasis).

This is echoed by Miroslav Volf from a wider perspective: "In recent decades the issue of identity has risen to the forefront of discussions in social philosophy. In the liberation movements of the sixties were all about equality - above all gender and race equality major concerns in the nineties seem to be about identity - about the recognition of distinct identities of persons who differ in gender, skin colour, or culture (Volf 1998:23, my emphasis).

The question in a post-apartheid country is how we can assert the right to be different without succumbing to a debilitating, hierarchically structured pluralism nor giving up the notion of an emerging, shared South Africanism. One answer is to build precedent communities where the freedom to be different is upheld and celebrated in community. The unity of the church, a unity in freedom (Moltmann), points in this direction.

The prophetic vision of a peaceable kingdom in Isaiah 11 can be interpreted as the radical transformation of identities through a knowledge of the Lord where "natural" divisions and enmities (wolf and lamb, calf and lion, child and viper) no longer lead to harm or destruction.

The creation of a prophetic community at the first Pentecost is an equally powerful testimony that differences in gender, culture and age can become reciprocal gifts in the one church. Sons and daughters prophesy, the languages of the time (representing different cultures) are freely spoken and understood, the Spirit is poured out

12 See the detailed discussion of apartheid theology's origin in Kuyper, Warneck and Pietism by Naude (Naude 2005a), as well as the extensive references to original sources. 
on all flesh, including both men and women, and old people dream dreams (Ac 2:17-21) . But they all form part of one body where members devoted themselves to koinonia (fellowship) and had everything in common (Ac 2:42-47). They were, in Pauline imagery, different members serving one another in one body (1 Cor 12).

We can refer to the Pauline vision that in Christ gender, cultural divisions and class do not disappear, but they are relativised in an egalitarian faith community where all become children of Abraham (Gl 3:26-28). The diverse and "naturally" divided faith community should now use their freedom to "serve one another in love" (Gl 5:13-15).

This unity in freedom and service is powerfully expressed in the Belhar confession: We believe, confesses Belhar, that unity in the church can only be embodied "in freedom and not through force". Difference and varieties of language and culture "are opportunities to reciprocal service and enrichment in the one visible people of God" (Belhar 1986, statement 2, my translation) ${ }^{13}$.

The critical question to the institutional churches in South Africa is whether we are indeed such precedent communities where difference-in-community is embodied. In my view the answer is no. Churches, who are structurally one, harbour in themselves deep racial and class divisions. In many churches gender is still a basis for leadership discrimination. The dramatic growth of charismatic churches is often sadly accompanied by little concern for unity and a complete absence of a deeper and wider ecumenical vision. Historical churches built their identities so strongly on their distinctive histories, liturgical practices and doctrinal convictions that the only option that remains is to be different - in - disunity.

This is not just an innocuous institutional deficit. The shame of disunity and the inability to build communities - of difference - is a reflection on the very suffering of Christ. Moltmann rightly points out the unity of church is the unity of Christ (1977:338). And in Christ's last prayer, according to the Johannine gospel, unity amongst the disciples and those who would believe after them, became the criterion of both the unity between Father and Son, and

13 For Belhar's original Afrikaans text, and an accessible, explanatory discussion, see Botha and Naude 1998. 
the one witness that may bring the world to believe in the mission of the Son (Jn 17). Our disunity is a recrucifixion of Christ.

For many in South Africa the church (and therefore Christ) no longer provides hope for the growth of new identities in difference, freedom and service. Two other powerful public institutions have taken over this role: sporting bodies and corporate business. If ever there were a reason for secular faith, this is it.

\section{HOW DO WE CREATE, SUSTAIN AND LIVE A SHARED VALUE-ORIENTATION? THROUGH THE HOLI- NESS OF THE CHURCH.}

Few debates after 1994 are so recurring as the "moral regeneration" of South Africa. The well-known phrase that we need an "RDP of the soul” (Mandela) still rings loudly. The ANC has - in an effort to stem crime and lawlessness - dedicated state resources and portfolio's at all three levels of government to the issue of anticorruption and rebuilding the moral fibre of the country. Despite a theoretical and legal consensus on those values that bind us together as expressed in the preface to the Constitution ${ }^{14}$ and embedded in the Bill of Rights, the chasm between the rule of law and an anomic ${ }^{15}$ society is growing. No surprisingly, the churches (and other religious communities) are regularly called upon to make a contribution in this regard. Moral regeneration seems like the churches' only avenue to still claim public and political relevance in a situation where economics and law have usurped the power of theology to shape the nation.

There is a complex relation amongst narrative, education, religion and moral formation ${ }^{16}$. In stead of dealing with the flood of

14 The constitution was accepted as Act 108 of 1996. The preamble says: "We, the people of South Africa, believe that South Africa belongs to all who live in it, united in our diversity", and focuses on values such as democracy, social justice, freedom, and quality of life (my emphasis).

15 The term "anomie" ("no law”) stems from French sociologist, Emile Durkheim, and describes a society with low social cohesion and valuedisorientation due to abrupt social transitions. See Naude 2005c: 539, footnote 6 for an explanation and reference.

16 In South Africa reflections on ecclesiology, liturgy, narrative and moral character were specifically prompted in dialogue with the work of American Methodist theologian, Stanley Hauerwas. He develops Christian ethics around themes of moral agency, community (church) and character (see an early 
literature in this regard, let us simply look into the well known Deuteronomic passage following the shema in Deuteronomy 6:4. Let us accept the canonical presentation of Deuteronomy (literally: "second law") as the farewell speech of Moses on the eve of the wandering people's sojourn into the promised land. He repeats the Ten Commandments in Deuteronomy 5 and then turns to the parent community: "These commandments that I give you today are to be upon your hearts. Impress them on your children” (Dt 6:6-7a).

How would such "impression" take place? The answer in the text is clear and gives an interrelated account of how "moral formation" took place: Through verbal and written repetition of the law to children $(6: 7,9)$, through symbolic representation (6:8), through conduct/example shaped by the commandments (6:17-18), and through a recounting of the exodus narrative as explanation for liturgical expressions of the law (6:20ff). This "impression" would mark the distinctiveness of God's people as a holy people in a land of competing gods and alternative moralities.

Although not present in the same condensed form, the early New Testament church communities were communities of moral instruction and moral formation ${ }^{17}$. Christ is the church's holiness (1 Cor 1:30) , early oral traditions and later written traditions served as memories of Him (Lk 1:1-4); those strong in faith are to serve as examples to others (1 Cor 8), moral injunctions to live according to the Spirit and be holy rest upon justification by faith (Gl 3:13-26; 1

example in Hauerwas 1983). At least five South African theologians, Neville Richardson, Nico Koopman, Robert Volsoo, Andrew Philips and De Wet Strauss wrote doctoral dissertations on Hauerwas. They and others like Dirkie Smit from Stellenbosch, and Pretoria ethicist, Etienne de Villiers, have since made solid contributions to what may broadly be termed a virtue ethic. For a short, informative overview of virtue ethics, see Jean Porter's contribution to the Cambridge Companion to Christian Ethics (Porter 2001). For an important view on the relation between ethics and ecclesiology in the ecumenical movement, see Best and Robra 1997 where the notion of the church as "moral community" is made explicit.

17 See the well-known publication of Wayne Meeks (1983) on the moral world of early Christian communities, and the attempt by Allen Verhey (2002) to reconstruct a contextual ethics of Jesus based on the notion of instructing faith communities (see his discussions of remembrance and the early church as a community of moral discourse (2002:3-33). 
Pt 1:13-16); and the sacraments served as symbolic representations of Christ's life and work (1 Cor 11:23-26).

These (and other) considerations bring the holiness of the church in fruitful relation to moral formation in post-apartheid South Africa. In stead of becoming a cheap political ally to a government clearly at loss over "moral regeneration", the church must know: Democracy and the law of the land do not equal the law of God or the rule of Christ. Christians' greatest contribution to "morality" is to live in the various spheres of civil and public life as ethical minority if required whilst involving themselves continuously in the task of "impressing" the law and gospel upon the next generation.

Holiness is not an outdated, conservative life shielded from the world behind church or monastery walls. It is life "set aside" for God exactly in the realities of the world. The church as ecclesia reformata et semper reformanda testifies to the coming reformatio mundi (Moltmann 1977:355) The "stabilizing" contribution that politicians covertly hope the church would make to morality, may turn - as Moltmann aptly showed - into a "cult of institutiona-lisation". This cult needs to be resisted by the exodus church as she follows in the footsteps of Christ, living the values of the kingdom of God as presented by Jesus in his love for the convicts, the poor and the outcast. "The church is therefore sanctified where it participates in the lowliness, helplessness, poverty and suffering of Christ” (1977:355). This is a partisanship (Moltmann) that might be seen as destabilising, and undermining the authority of the state.

\section{HOW DO WE RESPOND TO GLOBALISATION? THROUGH THE CATHOLICITY OF THE CHURCH}

Globalisation may be seen as complex processes of culture, economy and politics that create an apparent unified, boundary-less world ${ }^{18}$. Through information technology the physical boundaries and limitations of geography and space are overcome. Through mainly the Anglophone culture and language, previous differentia-tions are homogenised, thus limiting communication boundaries. Through the

18 Renowned political scientist, David Held, analyses globalisation in terms of culture, economics and politics (see Held 2000). I follow the short but incisive exposition by Dirkie Smit (2003) who applies various insights into globalisation to the lack of urgency regarding "unity" in our South African context. 
"triumph" of capitalism after 1989, standardized ideas about development - predicated on the vision to bring third world nations up to the example of industrialised nations - erode the authority of autonomous states, as all are required to respond to the standardized commodification of life.

The unity of a global world is not a unity that results from the free choice of individuals or nations. It is the unity brought upon us in a in "a runaway world" (Giddens, see Smit 2003:307), creating a "one way traffic" from mostly American and Western culturaleconomic interest to the rest of the world. Globalisation in many senses creates a mirage of unity and community, but is in fact an intensification and acceleration of modernity's individuation ${ }^{19}$.

Yes, globalisation in its varied forms brought enormous technological and information advances in the world. There are undoubtedly gains in efficiency and knowledge from which institutional and free churches also benefit, whilst they themselves become agents of globalization. But, one may speak of the Janus face of globalisation. The dark side of the face is evident in at least two phenomena:

First on the surface level, the promise and advantages of globalisation are favouring the strong and marginalize the weak nations, indigenous peoples, and the non-human environment. Second on a deeper level, globalisation provides a value-laden metanarrative that usurps all counter narratives as it establishes its authority via science, technology (especially the mass media) and digital capitalism ${ }^{20}$.

How does the confession of the church's catholicity ${ }^{21}$ relate to the latter destructive dimensions of globalisation?

19 See Smit's reference here to the work of Peter Berger and Samuel Huntington who write: "If there is one theme that all different sectors of cultural globalisation have in common, it is individuation...”. See Smit (2003:308) for references. It is immediately apparent that the unity and catholicity of the church are two sides of the same coin.

20 See Naude (2005c) for a discussion of the homogenisation implied by globalisation whilst apparently fostering differentiation, and the effect of this on ethics and identity formation.

21 For the various senses of "catholicity” in church history, see McGrath (2005:500-503). 
Because God is "catholic" in the sense of being "universal”, God's kingdom is equally catholic in its reach. The kingdom is meant to be established spatially in the entire world. But it is also meant to be established qualitatively in its wholeness (catholicity) or in its entirety. The church as first fruit of the kingdom is therefore called to establish this kingdom in the whole world and in its entirety.

The church "remains limited, non-universal and non-catholic until 'every rule and every authority and power' is destroyed (1 Cor 15:24)" (Moltmann 1977:350). This does not mean that the church should become a power amongst or against other powers (economic or political), but that its power - like that of Christ - lies in it powerlessness.

The church therefore combats the assumed and unchallenged authority of globalisation as "the only way", as the "true story", with the confession of Christ's universal (catholic) lordship. We follow the earliest Christians who confessed that not the Roman emperor (the global power of the day), but Jesus is the kurios. And this lordship is shown exactly where "the church as property of God stands where He stands, namely against all injustices and with the oppressed." The church must witness "against all powerful and privileged who selfishly seek their own interest whilst ruling over others and disadvantage them” (Belhar, statement 4).

Whilst this was a predominantly racial issue at the time of Belhar's formulation in the period 1982-1986, it has now become a more focused class issue. As the ANC government moved from RDP (Reconstruction and Development) to GEAR and now to ASGISA ${ }^{22}$, it has increasingly bought into the growth and development ideology of the global markets. As powerful politicians move into the private sector, a new elite and confined middle class are created, establishing a clear line between weak and strong in this country, reflecting the same structure as global inequalities between North and South. With adequate resources ${ }^{23}$, but an inability to deliver at

22 This stands for Accelerated and Shared Growth Initiative for South Africa and falls directly under control of the deputy-president. The aim is to achieve a growth rate of $6 \%$ by 2008.

23 The notion of "adequate resources" is obviously contextually defined. I simply refer to the fact that just over R44bn has been collected above budget in the 2005-6 financial year, and the numerous examples of unspent millions in 
local level, protest action (more than 900 in 2005) returned to our shores. There are too many South Africans who do not see and experience the benefits of the system.

The church is partisan and particular exactly to demonstrate the universal love and reign of God. "Christian partisan support for the oppressed is intentional and its goal is to save the oppressor also... Christian universalism will therefore be realized in particular conflict situations in a partisanship of this kind; otherwise it is still in danger of being abstract...” (Moltmann 1977:352).

This particular partisanship is an ecclesiological expression of glocalization: We make God's global love concrete in specific local options for the oppressed.

\section{HOW DO WE RELATE TO MARGINALIZED PEOPLE AND OUR NON-HUMAN ENVIRONMENT? THROUGH THE APOSTOLICITY OF THE CHURCH.}

The concept of marginalized or vulnerable people requires description in each specific society and may be identified on a more universal scale. An example of the latter is "indigenous peoples" scattered around the globe and presently the subject of intense United Nations activities ${ }^{24}$.

Who are the vulnerable and (in most cases) marginalized people in present day South Africa? It will be difficult to reach full agreement on this issue. My understanding would include rural women; most people with HIV/AIDS; illiterate adults; unemployed people $^{25}$; orphans; refugees within our borders, and people living

socially sensitive departments like housing and health care at provincial government level.

24 The UN estimates that about $6 \%$ of the world's population are "indigenous people" based on a combination of historical, cultural, and geographical factors. The period 2005-2014 has been declared as the Second International Decade of the World's Indigenous People. See reference to Wikipedia Encyclopedia in bibliography.

25 According to the Markinor survey of 2000, 30.7\% of the adult population was unemployed at that stage. Economists differ about the very definition of "unemployment" and figures vary accordingly. See Erasmus and Hendriks (2003:94). 
under the poverty line as defined in our context ${ }^{26}$. A simple calculation would bring the number of people in these categories to around 8-10 million or roughly a quarter of our population. The current debates about eco-tourism and golf estates, nuclear power and renewable energy resources, and the retention of biodiversity clearly put our natural environment in the category of vulnerability.

We may understand the apostolicity of the church as its foundation, namely that it is based on the testimony of the apostles, eyewitnesses of the resurrection. We may also understand it as the task or commission of the church, namely to participate in the apostolic mission of Christ (Mt 28:19-20; Ac 1:8).

Many churches in South Africa understand and show great enthusiasm for mission in the sense of teaching others "who have not heard of Christ" to convert to the Christian faith. This is undoubtedly a dimension of the church's apostolicity. But in the context of South Africa where the gospel is widely known,27 apostolicity clearly requires much more. The answer lies in participating in Christ's mission in a specific manner.

To reduce Jesus' ministry to "the great teacher" is misleading. Jesus did not come to only proclaim or teach a new message. Yes, he undoubtedly preached and taught. But he saw himself in the prophetic tradition (Lk 4:14-21) and complemented his teaching in many different ways: He healed the sick who were marginalized by strict social and legal codes; he befriended the socially insignificant and despised; he dined with the enemies of the people; he empowered women who were socially and religiously marginalized through patriarchal gender relations and customs; he undermined religious custom through boundary-less love. In the words of an early hymn: He did not cling to the Godhead, but made Himself

26 By 2000 the poverty threshold was set at R1 400 per month per household. An average of $64.4 \%$ fell in this category (Erasmus and Hendriks 2003:93). Recent economic growth might have eased this figure, but the extent of absolute poverty is still vast.

27 See the regular updates of religious affiliation done by the Unit for Religious and Demographic Research at the University of Stellenbosch. The association with Christianity is slightly in decline, but was still at a high $77 \%$ of the population in 2000. See Erasmus and Hendriks (2003) and references to their earlier work in footnote 1. 
nothing; he humbled himself and became obedient to death on the cross... (Phlp 2:6-8).

An apostolic church is a "nothing" church. It is a doulos (slave) church. It is a cross-bearing church. You find her and her members on the margins of society. Because the church knows from Matthew 25 that Christ meets them in the clothing of half-dressed children and in the embrace ${ }^{28}$ of those who die of Aids without access to basic life-saving medical provisions.

\section{CONCLUSION}

In a situation of competing identities and conflicting differences, the one church is a precedent community of unity in freedom, joy and reciprocal service.

In a situation of anomie and moral bewilderment, the holy church engages in fruitful moral formation according to the law and gospel, and in a "destabilizing" commitment to the values of God's kingdom.

In a situation of increasing globalisation, the catholic church confesses one lord, Jesus Christ, and practices his universal love in partisan service to the oppressed.

In a situation of so many marginal people and an exploited ecosystem, the apostolic church stands where God stands - against injustice and slaving in its mission for the sake of the despised.

I close with a question:

If the marks of the church are inferred from the triune God, is this how God will be known in South Africa?

\section{Consulted literature}

Balcomb, T 1998. From liberation to democracy: Theologies of bread and being in the new South Africa. Missionalia 26/1, 54-73.

Best, T F and Gobra, M (eds.) 1997. Ecclesiology and ethics. Ecumenical engagement, moral formation and the nature of the church. Geneva: WCC.

Botha, J en Naude, P 1998. Op pad met Belhar, Goeie nuus vir gister, vandag en môre. Pretoria: JL van Schaik.

28 See Naudé's description - in dialogue with Miroslav Volf - of the church as "embracing and healing community" amidst the HIV/AIDS pandemic (Naude 2005c:438-439). 
De Gruchy, J (with Steve de Gruchy) 2004. The church struggle in South Africa. 25th Anniversary edition. London: SCM

Erasmus, J C and Hendriks, J 2003. Religious affiliation in South Africa early in the new millennium: Markinor's world values survey. JTSA 117, 80 - 96.

Hauwerwas, S 1983. The peaceable kingdom: A primer in Christian ethics. Notre Dame: University of Notre Dame Press.

Held, D 2000. A globalizing world? Culture, economics, politics. New York: Routledge.

Meeks, W 1983. The first urban Christians: The social world of the apostle Paul. New Haven: Yale University Press.

McGrath, A E 2005. Christian theology: An introduction (third edition). London: Blackwell.

Moltmann, J 1967. Theology of hope. On the ground and implications of a Christian eschatology. London: SCM.

-, 1974. The crucified God. The cross of Christ as the foundation and criticism of Christian theology. London: SCM.

-, 1977. The church in the power of the Spirit. A contribution to messianic ecclesiology. London: SCM.

Naude, P 2005a. From pluralism to ideology: The roots of apartheid theology in Abraham Kuyper, Gustav Warneck and theological Pietism. Scriptura 88:161-173.

-, 2005b. 'It is your duty to be human': A few theological remarks amidst the HIV/AIDS crisis. Scriptura 89, 433-440.

-, 2005c. The ethical challenge of identity formation and cultural justice in a globalising world. Scripture 89, 536-549.

Porter, J 2001. Virtue ethics. In Gill, Robin (ed.) The Cambridge companion to Christian ethics. Cambridge: CUP, 96-111.

Smit, D J 2003. Unity in church and society? Theological reflection on an ongoing challenge in South Africa today. Scriptura 83, 305-314.

-, 2006. Church unity in freedom: Integral to the confession of the triune God? In Welker, Michael and Volf, Miroslaf (eds.) Trinity and God's life. Minneapolis: Fortress, 73-92.

Sobrino, J 1983. The true church and the poor. London: SCM

Verhey, A 2002. Remembering Jesus. Christian community, Scripture and moral life. Grand Rapids: Eerdmans.

Volf, M 1988. “The trinity is our social program”: The doctrine of the trinity and the shape of social engagement. Modern Theology 14/3, July, 403- 423.

Welker, M und Volf, M (Hrsg.) 2006. Der lebendige Gott als Trinität. Jürgen Moltmann zum 80.Geburtstag. Gütersloh: Gütersloher Verlagshaus.

Wikipedia Encyclopedia: http://en.wikipedia.org/wiki/Indigenous_Peoples. 